\title{
Studies Of Analgesic and Anti-Inflammatory Effects of Aqueous Extract Of Ganoderma Lucidum in Mice and Wister Rats
}

\author{
${ }^{1}$ Mohammed A, ${ }^{1}$ Tanko Y., ${ }^{1}$ Mohammed K.A and ${ }^{2}$ Yaro A.H. \\ ${ }^{1}$ Department of Human Physiology, Ahmadu Bello University, Zaria,Nigeria \\ ${ }^{2}$ Department of Pharmacology, Bayero University, Kano,Nigeria \\ Corresponding Author: \\ Mohammed A : Department of Human Physiology, Faculty of Medicine, Ahmadu Bello University, Zaria
}

\begin{abstract}
The aqueous extract of Ganoderma lucidum was investigated for analgesic and anti-inflammatory effects in rodents. Investigations for analgesic effect was carried out employing the acetic acid-induced writhing in mice and the anti-inflammatory effect the hind paw edema method was employed in Wistar rats Results showed the aqueous extract to have a significant $(p<0.05)$ analgesic activity at the doses of 50, 100 and $150 \mathrm{mg} / \mathrm{kg}$ body weight intraperitoneally in mice. Also, the extract showed a significant $(p<0.05)$ antiinflammatory activity at doses of 50, 100 and $150 \mathrm{mg} / \mathrm{kg}$ body weight. Preliminary phytochemical screening of the aqueous extract revealed the presences of Glycosides, Saponins, Flavonoids, Alkaloids, Steroids and Reducing sugars. The extract had an $L D_{50}$ of $3.5 \mathrm{~g} / \mathrm{kg}$ body weight in Wistar rats. The results of this study confirms that the aqueous extract of Ganoderma lucidum have analgesic and anti-inflammatory activities in mice and rats.
\end{abstract}

Key words: Ganoderma lucidum: acetic acid induced writhing: analgesic: anti-inflammatory.

\section{Introduction}

Mushrooms have a notable place in the folklore throughout the world and in the traditions of many cultures [ 1] .The family of Ganodermataceae consists of a large group of tree fungi of the class Polyporaceae, specifically the genus Ganoderma and other related genera. Ganoderma fungi are mainly found in tropical and subtropical areas; the typical species is Ganoderma lucidum (Fr.) Karst. It is called Ling Zhi or Reishi(Chinese), Mannentake (Japanese) and Tuwon biri (Hausa).It is seasonal and can be found growing alone or in groups on decaying hardwood logs and stumps. At first, the caps are irregularly knobby or elongated, but by maturity more or less fan-shaped; with a shiny, varnished surface often roughly arranged into lumpy "zones"; red to reddish brown when mature; when young often with zones of bright yellow and white toward the margin. The stem is sometimes absent, but more commonly present; $3-14 \mathrm{~cm}$ long; up to $3 \mathrm{~cm}$ thick; twisted; equal or irregular; varnished and colored like the cap; often distinctively angled away from one side of the cap. The under side is cream colored and porous. Garnoderma lucidum is commonly known as a medicinally-potent mushroom. It has been widely used in China and other oriental countries for hundreds of years for the treatment of various diseases, including cancer. This mushroom is reported to have various biological activities, such as anti-tumor, antibacterial, and antiviral activities [2,3,4,5]. It was also reported to have an anti-inflammatory and liver protective effect in rats[ 6,7$]$.

This research was aimed at investigating the possible anti-nociceptive and anti-inflammatory activities of ethanol extract of the plant, in order to support or refute the claims by traditional herbalists.

\subsection{Location of Study}

\section{Materials and Methods}

This research was carried out in the Department of Human Physiology Faculty of Medicine, Ahmadu Bello University, Zaria. Nigeria

\subsection{Drugs}

All chemicals and drugs used were obtained commercially and of analytical grade.

\subsection{Collection of Plant Material}

Fruiting bodies of Ganoderma lucidum were collected within Ahmadu Bello University Main campus Zaria in the month July 2006. The plant material was identified by Dr.P.A.Wuyep of Biological Science Department A.B.U., Zaria where a voucher specimen (No.BSTCC 005) has been deposited at the herbarium unit. 


\subsection{Extraction of Plant Material}

The fruiting bodies were dried under the shade and ground into powder. The powder $(500 \mathrm{~g})$ was macerated in $2.5 \mathrm{~L}$ of distilled water at room temperature for 24 hours. It was then filtered using a filter paper (Whatmann size, No 1) and the filtrate evaporated to dryness in water bath at $40^{\circ} \mathrm{C}$. A brownish residue weighing 25.5 grams was obtained which was kept in air tight bottles in a refrigerator until use

\subsection{Animal Management}

Wistar albino rats (170-200g) and Swiss albino mice (18-22g) of either sex were used for the various experiments. All the animals were obtained from the animal house of the Pharmacology and Clinical Pharmacy Department of Ahmadu Bello University, Zaria, Nigeria. They were kept under standard conditions of temperature, relative humidity and 12 hours light/dark cycle. They were fed with excel feeds (Feed Masters PLC, Kaduna) and water ad libitum. This research was carried out in Ahmadu Bello University in accordance with the rules governing the use of laboratory animals as accepted internationally.

\subsection{Acute toxicity study:}

\section{Experimental Procedures:}

The method of [ 8] was adopted and a total of 24 rats weighing 120-145 grams each were used for this study. The animals were fasted for 12 hours before the study, but were allowed water ad libitum. In the initial phase, four groups(n=3) were given normal saline as control group and $100 \mathrm{mg} / \mathrm{Kg}, 1000 \mathrm{mg} / \mathrm{Kg}$ and $10,000 \mathrm{mg} / \mathrm{Kg}$ of the extract intraperitoneally $(i . p)$ for the remaining three groups respectively. They were then observed for 24 hours for signs of toxicity or deaths. In the final phase, another four groups(n=3) were given normal saline, $2000 \mathrm{mg} / \mathrm{Kg}, 4000 \mathrm{mg} / \mathrm{Kg}$ and $8000 \mathrm{mg} / \mathrm{Kg}$ of the extract i.p for the remaining groups respectively and were observed for 24 hours for signs of toxicity or deaths. The median lethal dose $\left(\mathrm{LD}_{50}\right)$ was calculated from the final phase.

\subsection{Phytochemical Screening:} [9].

The extract was screened for the presence of various phytochemicals employing standard screening test

\subsection{Analgesic Study:}

The method described by [10] was employed in this experiment. Swiss albino mice were divided into four groups (5 mice per group). The first group served as control while the second were treated with $20 \mathrm{mg} / \mathrm{kg}$ Piroxicam, while the third fourth and fifth groups received the extract at doses of 50,100 and $150 \mathrm{mg} / \mathrm{kg}$ (i.p) respectively. 30 minutes before acetic acid injection $(0.6 \%, 1 \mathrm{~m}$ in $100 \mathrm{~g}$ i.p). The mice were placed in individual cages. The number of abdominal contractions was observed 5 minutes after stimulation during a period of 10 minutes. Percentage inhibition of writing was calculated using the formula:

Inhibition $(\%)=\underline{\text { Control mean }- \text { Test mean } \mathrm{x} 100 \%}$

Control mean.

\subsection{Anti-inflammatory Study:}

The method of [11] as slightly adopted by [12] was employed. Injecting $0.1 \mathrm{~m} 1$ fresh egg albumin into the subplantar surface of the right hind paw induced the inflammation. The control group was given normal saline, the second group received Piroxicam $(20 \mathrm{mg} / \mathrm{kg})$, while the remaining 3 groups received the extract at doses of 50,100 and $150 \mathrm{mg} / \mathrm{kg}$ (i.p) a displacement technique using digital plethysmometer (LE7150), before and every 20 minutes after the injection of egg albumin for the period of 2 hours was used to measure foot volume.

\subsection{Statistical Analysis:}

The result of the experiment are expressed as mean \pm SEM. Analysis of variance was performed and sequential differences among the means were calculated at a level of $\mathrm{P}<0.05$ [13].

\subsection{Phytochemical analysis:}

\section{Results}

Phytochemical analysis of Ganoderma lucidum revealed that it contains the following viz ; Glycosides, saponins, flavonoids, alkaloids, steroids and reducing sugars.

\subsection{Acute toxicity study:}

Signs of toxicity were first noticed after 4-5 hours of aqueous extract administration. There were decreased locomotor activity and sensitivity to touch and pain. Also there was decreased feed intake, tachypnoea and prostration after 8-12 hours of aqueous extract administration. 


\subsection{Analgesic Study:}

The extract $(50 \mathrm{mg} / \mathrm{kg} 100$ and $150 \mathrm{mg} / \mathrm{kg}$ i.p) produced a significant anti-nociceptive when compared to normal saline $(\mathrm{P}<0.05)$ with the highest percentage inhibition of 88.3 which reside at the lowest dose, as showed in TABLE 1

\subsection{Anti-inflammatory Study:}

The extract $(50 \mathrm{mg} / \mathrm{kg} 100$ and $150 \mathrm{mg} / \mathrm{kg}$ i.p $)$ produced a significant anti-inflammatory activity when compared to normal saline $(\mathrm{P}<0.05)$, as showed in TABLE 2

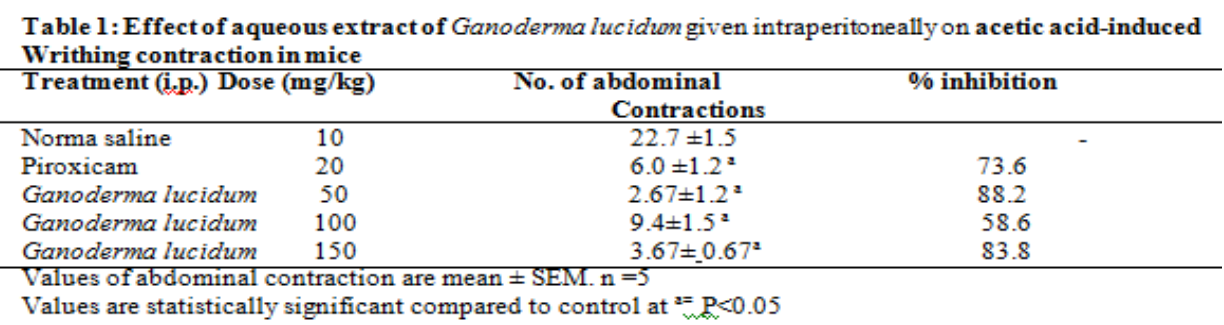

Table 2: Paw volume (ml) at various times post albumin- induced edema in Wistar rats of aqueous extract Ganoderma lucidum and controls.

\begin{tabular}{|l|l|l|l|l|l|l|l|}
\hline $\begin{array}{l}\text { Treatmen given } \\
(\mathrm{Mg} / \mathrm{kg})\end{array}$ & $0 \mathrm{~min}$ & $20 \mathrm{mins}$ & $40 \mathrm{mins}$ & $60 \mathrm{mins}$ & $80 \mathrm{mins}$ & $100 \mathrm{mins}$ & $120 \mathrm{mins}$ \\
\hline Normal saline & $0.127 \pm 0.0053$ & $0.252 \pm 0.0282$ & $0.216 \pm 0.0352$ & $0.290 \pm 0.0605$ & $0.176 \pm 0.0383$ & $0.134 \pm 0.0112$ & $0.160 \pm 0.0197$ \\
\hline Piroxicam 20 & $0.150 \pm 0.0055^{\mathrm{ns}}$ & $0.234 \pm 0.0466^{\mathrm{ns}}$ & $0.238 \pm 0.0206^{\mathrm{ns}}$ & $0.162 \pm 0.0196^{\mathrm{a}}$ & $0.172 \pm 0.0183^{\mathrm{ns}}$ & $0.160 \pm 0.0155^{\mathrm{ns}}$ & $0.156 \pm 0.0204^{\mathrm{ns}}$ \\
\hline Extract 50 & $0.188 \pm 0.029^{\mathrm{ns}}$ & $0.182 \pm 0.0183^{\mathrm{ns}}$ & $0.190 \pm 0.032^{\mathrm{ns}}$ & $0.190 \pm 0.0241^{\mathrm{ns}}$ & $0.136 \pm 0.0264^{\mathrm{ns}}$ & $0.108 \pm 0.0183^{\mathrm{ns}}$ & $0.120 \pm 0.0084^{\mathrm{ns}}$ \\
\hline Extract 100 & $0.146 \pm 0.0232^{\mathrm{ns}}$ & $0.270 \pm 0.0265^{\mathrm{ns}}$ & $0.232 \pm 0.0263^{\mathrm{ns}}$ & $0.162 \pm 0.0196^{\mathrm{a}}$ & $0.160 \pm 0.0235^{\mathrm{ns}}$ & $0.124 \pm 0.0248^{\mathrm{ns}}$ & $0.114 \pm 0.0108^{\mathrm{a}}$ \\
\hline Extract 150 & $0.118 \pm 0.0080^{\mathrm{ns}}$ & $0.180 \pm 0.0428^{\mathrm{ns}}$ & $0.134 \pm 0.0191^{\mathrm{ns}}$ & $0.120 \pm 0.0152^{\mathrm{a}}$ & $0.108 \pm 0.0058^{\mathrm{ns}}$ & $0.096 \pm 0.0051^{\mathrm{ns}}$ & $0.098 \pm 0.0058^{\mathrm{a}}$ \\
\hline
\end{tabular}

Values of paw volume are mean \pm SEM. $n=5$

Values are statistically significant compared to control at; ${ }^{a} \mathrm{P}<0.05$ While ${ }^{\text {ns not }}$ significant.

\section{Discussion}

The phytochemical constituents (flavonoids, tannins, glycosides, alkaloids and steroids) of the aqueous extract of Ganoderma lucidum might be responsible for the observed pharmacological activities of the extract. The anti-nociceptive potency of the extract is comparable to that of piroxicam, a standard non-steroidal antiinflammatory drug(NSAID). Although acetic acid-induced pain (also called the abdominal constriction response) is a non-specific model, it is widely used for the evaluation of peripheral anti-nociceptive activity [14]. It is very sensitive and able to detect anti-nociceptive effects of compounds at dose level that may appear inactive in the other methods like the tail flick test $[15,16]$. Local peritoneal receptors are postulated to be partly involved in abdominal constriction response [17] The method has been associated with prostanoids in general, e.g. increase level of $\mathrm{PGE}_{2}$ and $\mathrm{PGF}_{2 \alpha}$ in peritoneal fluids [18] as well as lipoxygenase products by some researches $[19,20]$. In the formalin test, which measures pain of both neurogenic (first phase) and inflammatory (second phase) origins [21], the extract preferentially inhibited the second phase of the response (inflammatory reaction in the peripheral tissues) and also produced a strong anti-inflammatory effect on the formalin-induced paw oedema that was comparable to that of piroxicam. Analgesic and anti-inflammatory effects have been observed in flavonoids as well as tannins [22,23]. Certain flavonoids possess potent inhibitory activity against a wide array of enzymes such as protein kinase $\mathrm{C}$, protein tyrosine kinases, phospholipase $\mathrm{A}_{2}$,phosphodiesterases and others[24] . Other flavonoids [25], potently inhibits prostaglandins, a group of powerful pro-inflammatory signaling molecules. Inhibition of these key enzymes provides the mechanism by which flavonoids inhibit inflammatory processes [26]. Deleterious effects of excessive releases of nitric oxide (NO) have been implicated in tissue damage and inflammation. Tannic acid and polyphenols have been shown to be potent inhibitors of NO synthetase activity and NO production, independent of their antioxidant activity [27]. The analgesic and anti-inflammatory properties observed might thus be related in part to the flavonoids content of this plant. The results are consistent with the study of [28] reported the used of methanol and ethyl acetate extracts .Both extracts produced significant dose dependent inhibition of carageenan- induced acute and formalin induced chronic inflammation in mice. The extracts also showed marked analgesic activity compared to the standard reference drug. In another study [29,30] reported that the water extract was active orally against both carageenan- induced acute inflammation and cotton oil-induced chronic inflammation. Also in related study [6] found that water extract have significant anti-inflammatory activity against carageenan induced oedema.

\section{Conclusion}

This study has shown that the aqueous extract of Ganoderma lucidum does possess analgesic and antiinflammatory effects in laboratory animals at the doses tested. The results support the traditional use of this 
plant in some painful and inflammatory conditions and also suggest the presence of biologically active principles which may be worth further investigation and elucidation. Further studies are currently under way to isolate and characterize the active principle(s) of the crude extract.

\section{References}

[1] Chang,S.T.,and Buswell,J.A.(1996).Mushroom nutriceuticals.World J.Microbiol Biotechnol.12:473-476.

[2] Yoon, S. Y., Eo, S. K., Kim, Y. S., Lee, C. K. and Han, S. S.(1994) Antimicrobial activity of Garnoderma lucidum extracts alone and in combination with some antibiotics. Arch. Pharm.Res. 17, 438-442.

[3] Wang, S. Y., Hsu, M. L., Hsu, H. C., Tzeng, C. H., Lee, S. S.,Shiao, M. S. and Ho, C. K.(1997) The anti-tumor effect of Garnoderma lucidum is mediated by cytokines released from activated macrophages and T lymphocytes. Int. J. Cancer 70,699- 705.

[4] El-Mekkawy, S., Meselhy, M. R., Nakamura, N., Tezuka, Y.,Hattori, M., Kakiuchi, N., Shimotohno, K., Kawahata, T. and Otake, T. (1998) Anti-HIV-1 and anti-HIV-1- Protease substances from Garnoderma lucidum. hytochemistry 49,1651-1657.

[5] Eo, S. K., Kim, Y. S., Lee, C. K. and Han, S. S. (2000) Possible mode of antiviral activity of acidic protein bound polysaccharide isolated from Ganoderma lucidum on herpes simplex viruses. J. Ethnopharmacol. 72, 475-481.

[6] Lin J.M., Lin, C.C., Chiu, H.F, Yang, J.J., and Lee, S.G.( 1993): Evaluation of the anti-inflammatory and liver protective effects of anoectochils formosanus, Ganoderma lucidum and Gynostemma pentaphyllum in rats. Am J clin Med, 21(1);59-69.

[7] Lin, J. M., Lin, C. C., Chen, M. F., Ujiie, T. and Takada, A.(1995) Radical scavenger and antihepatotoxic activity of Garnoderma formosanum, Garnoderma lucidum and Garnoderma neo-japonicum. J. Ethopharmacol. 47, 33-41.

[8] Lorke, D. (1983): A new approach to acute toxicity testing. Archives of Toxicology 54, 275-287.

[9] Trease, G.E., Evans, M.C. (1983): Textbook of pharmacognosy. $12^{\text {th }}$ edition Ballieke Tindall. London. pp 343-383.

[10] Koster, R., Anderson, M., Debeer E.J. (1959). Acetic acid for analgesic screening Federation proceedings. $18 ; 412$.

[11] Winter, C.A., risely, E.A.., Nusss, G.V. (1962) Carragenin-induced oedema in hind paw of rat as an assay for anti-inflammatory drugs. Proceedings of the Society for Experimental Biology and Medicine. 11; 544-547

[12] Akah, P.A., Nwambie, S.I. (1994): Evaluation of Nigerian traditional medicines: Plants used for rheumatic (inflammatory) disorders. Journal of Ethnopharmacology; 42;179-182.

[13] Bolton, S. (1997): Pharmaceutical statistics. Practical and Clinical application. $3^{\text {rd }}$ Edition. Marcel Dekker In. New York. USA.

[14] Gene, R. M., Segura, L., Adzet, T., Marin, E., Ingelsias, J. (1998). Heterotheca inuloides: anti-inflammatory and analgesic effects. Journal of Ethnopharmacol. 60:157-162

[15] Collier, H. O. J., Dinnean, L. C., Johnson, C. A. and Schenider, C. (1968); The abdominal constriction response and its suppression by analgesic drugs in the mouse Bri. J. Pharmacol. 32:295-310.

[16] Bentley, G.A., Newtons, S.H. and Starr, J. (1983). Studies on the antinociceptive action of agonist drugs and their interaction with opioid mechanisms. Bri. J. Pharmacol. 9:125-134.

[17] Bentley, G.A., Newton, S.H. and Starr, J. (1981). Evidence for an action of morphine and enkephalins on sensory nerve endings in the mouse peritoneum. Bri. J. Pharmacol.73:325-332.

[18] Derardt, R., Jongney, S., Delvalcee, F. and Falhout, M. (1980). Release of prostaglandin's E and F in an algogenic reaction and its inhibition. Euro. J. Pharmacol. 51:17-24.

[19] Levini, J.D., Lau, W., Kwait, G. and Goetzl, E.J. (1984). Leukotriene B4 produces hyperalgesia that is dependent on the polymorphonuclear leucocytes. Sci. 225:743- 745 .

[20] Dhara, A.K., Suba, V., Sen, T., Pal, S. and Chaudhuri, A.K. (2000); Preliminary studies on the anti-inflammatory and analgesic activity of methanolic fraction of the root of Tragia involucrate. J. Ethnopharmacol. 72:265-268.

[21] Tjølsen, A., Berge, O. G., Hunskaar, S., Rosland, J.H. and Hole, K. (1992). The formalin test: an evaluation of the method. Pain. 51:5-17.

[22] Ahmadiani, A., Fereidoni, M., Semnanian, S., Kamalinejad, M. and Saremi, S. (1998). Antinoceptive and anti-inflammatory effects of Sambucus ebulus rhizome extract in rats. J. Ethnopharmacol. 61:229-235.

[23] Ahmadiani, A., Hosseiny, J., Semnanian, S., Javan, M., Saeedi, F., Kamalinejad, M., andSaremi, S. (2000). Antinociceptive and antiinflammatory effects of Elaeagnus angustifolia fruit extract. J. Ethnopharmacol. 72:287-292.

[24] Middleton, E. Jr. (1998). Effect of plant flavonoids on immune and inflammatory cell function. Adv. Exp. Med. Biol. 439: $175-182$.

[25] Manthey, J.A. (2000). Biological properties of flavonoids pertaining to inflammation. Microcircul. 7(6pt): S29-34.

[26] Manthey, J.A., Grohmann, K. and Guthrie, N. (2001). Biological properties of citrus flavonoids pertaining to cancer and inflammation. Curr. Med. Chem. 8:135-153.

[27] Srivastava, R. C., Hussain, M. M., Hassan, S. K., Athar, M. (2000). Green tea polyphenols and tannic acid act as potent inhibitors of phorbol esters-induced nitric oxide generation in rat hepatocytes independent of their antioxidant properties.Cancer Lett 153:1-5

[28] Sheena. N, Ajith, K., Janardhanan, K. (2003): Anti- inflammatory and Anti-nociceptive activities of Ganoderma lucidum occurring in South India. Pharmaceutical Biology, 41, 4, pp 301-304.

[29] Stavinoha, W., Slama, J., Weinstravels, S Mobley, P .(1991): The Anti-inflammatory activity of Ganoderma lucidum. Third International symposium of Ganoderma lucidum, 9-21.

[30] Stavinoha, W., Satsangi, N and Weinstravels, S.(1995): Study of the anti-inflammatory efficacy of Ganoderma lucidum. In: B-K, Kim and Y-S Kim (ed): Recent Advances in Ganoderma lucidum Research pp3-7. Seoul, Korea. The pharmaceutical society of Korea. 